\title{
Maps Showing Thermal Maturity of Upper Cretaceous Marine Shales in the Bighorn Basin, Wyoming and Montana
}

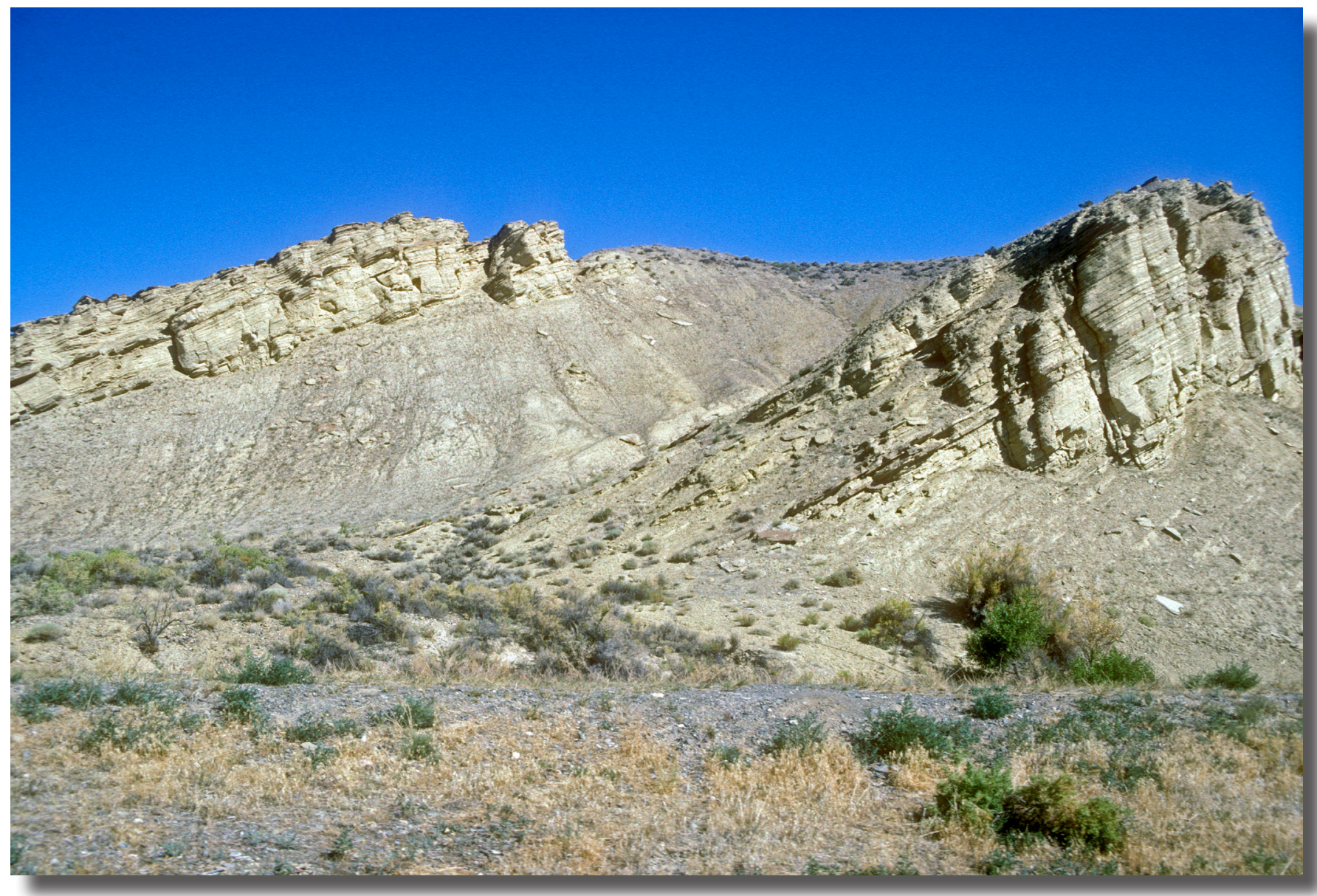

Scientific Investigations Map 3285 
Cover photograph: Upper part of Cody Shale near Greybull, Wyoming, east flank of the Bighorn Basin. Photograph by R.C. Johnson, 1994. 


\section{Maps Showing Thermal Maturity of Upper Cretaceous Marine Shales in the Bighorn Basin, Wyoming and Montana}

By Thomas M. Finn and Mark J. Pawlewicz

Scientific Investigations Map 3285 


\title{
U.S. Department of the Interior SALLY JEWELL, Secretary
}

\section{U.S. Geological Survey Suzette M. Kimball, Acting Director}

\author{
U.S. Geological Survey, Reston, Virginia: 2014
}

For more information on the USGS - the Federal source for science about the Earth, its natural and living resources, natural hazards, and the environment, visit http://www.usgs.gov or call 1-888-ASK-USGS.

For an overview of USGS information products, including maps, imagery, and publications, visit http://WwW.usgs.gov/pubprod

To order this and other USGS information products, visit http://store.usgs.gov

Any use of trade, firm, or product names is for descriptive purposes only and does not imply endorsement by the U.S. Government.

Although this information product, for the most part, is in the public domain, it also may contain copyrighted materials as noted in the text. Permission to reproduce copyrighted items must be secured from the copyright owner.

Suggested citation:

Finn, T.M., and Pawlewicz, M.J., 2014, Maps showing thermal maturity of Upper Cretaceous marine shales in the Bighorn Basin, Wyoming and Montana: U.S. Geological Survey Scientific Investigations Map 3285, 14 p., 3 sheets, scale 1:500,000, http://dx.doi.org/10.3133/sim3285. 


\section{Contents}

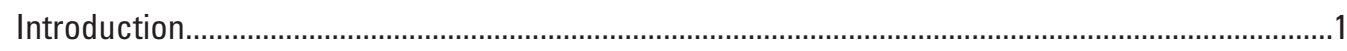

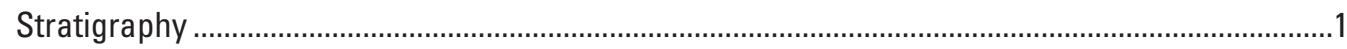

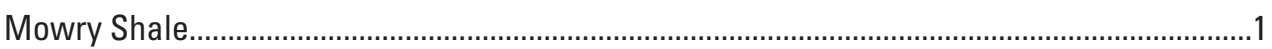

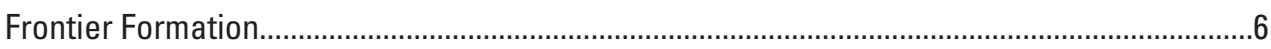

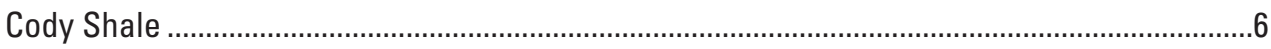

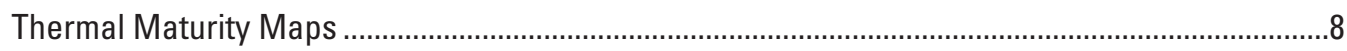

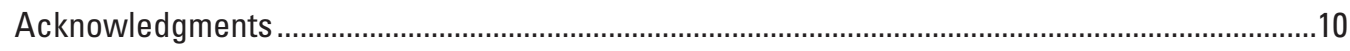

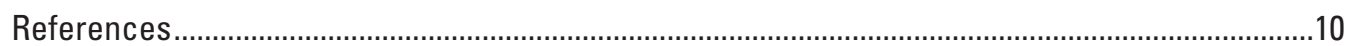

\section{Figures}

1. Map of Rocky Mountain region showing Laramide basins .............................................

2. Index map of the Bighorn Basin..........................................................................................

3. Correlation chart showing the stratigraphic relation of lowermost Upper Cretaceous rocks in the Bighorn Basin. ,

.

4. Regional stratigraphic cross section of Cretaceous rocks in the Bighorn Basin .............5

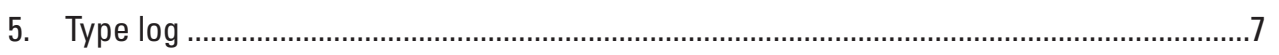

6. $\log (\mathrm{Ro})$ versus depth plot for the Amoco Production 1 Chapman Bench well ..................8

7. West-east structural cross section of the central part of the Bighorn Basin ..................9

\section{Sheets}

1. Map showing variations in vitrinite reflectance at the top of the Cody Shale, Bighorn Basin, Wyoming and Montana ......................................................................... link

2. Map showing variations in vitrinite reflectance at the top of the lower shaly member of the Cody Shale, Bighorn Basin, Wyoming and Montana.............................. link

3. Map showing variations in vitrinite reflectance at the top of the Mowry Shale, Bighorn Basin, Wyoming and Montana ...................................................................... link 



\title{
Maps Showing Thermal Maturity of Upper Cretaceous Marine Shales in the Bighorn Basin, Wyoming and Montana
}

\author{
By Thomas M. Finn, and Mark J. Pawlewicz
}

\section{Introduction}

The Bighorn Basin is one of many structural and sedimentary basins that formed in the Rocky Mountain foreland during the Laramide orogeny, a period of crustal instability and compressional tectonics that began in latest Cretaceous time and ended in the Eocene. The basin is nearly $180 \mathrm{mi}$ long, $100 \mathrm{mi}$ wide, and encompasses about 10,400 $\mathrm{mi}^{2}$ in north-central Wyoming and south-central Montana (fig. 1). The basin is bounded on the northeast by the Pryor Mountains, on the east by the Bighorn Mountains, and on the south by the Owl Creek Mountains (fig. 2). The north boundary includes a zone of faulting and folding referred to as the Nye-Bowler lineament (Wilson, 1936). The northwest and west margins are formed by the Beartooth Mountains and Absaroka Range, respectively (figs. 1 and 2).

Important conventional oil and gas resources have been discovered and produced from reservoirs ranging in age from Cambrian through Tertiary (Fox and Dolton, 1989, 1996a, b; De Bruin, 1993). In addition, a potential unconventional basin-centered gas accumulation may be present in Cretaceous reservoirs in the deeper parts of the basin (Ryder, 1987; Surdam and others, 1997; Johnson and Finn, 1998; Johnson and others, 1999; Finn and others, 2010). It has been suggested by numerous authors, including Burtner and Warner (1984), Hagen and Surdam (1984), Meissner and others (1984), Ryder (1987), and Fox and Dolton (1989, 1996a, b), that various Cretaceous marine shales are the principal source rock for these accumulations. Numerous studies of various Upper Cretaceous marine shales in the Rocky Mountain region by several authors, including Schrayer and Zarrella (1963, 1966, 1968), Nixon (1973), Clayton and Swetland (1977), Merewether and Claypool (1980), Burtner and Warner (1984), Hagen and Surdam (1984), Momper and Williams (1984), Davis (1986), Davis and others (1989), Nuccio (1990a, b), Longman and others (1998), Landon and others (2001), Roberts and others (2004, 2007, 2008), and Finn (2010a) have led to the general conclusion that these rocks have generated or are capable of generating oil and (or) gas.

In recent years, advances in horizontal drilling and multistage fracture stimulation have resulted in increased exploration and completion of wells in Cretaceous marine shales in other Rocky Mountain Laramide basins that were previously thought of only as hydrocarbon source rocks. Important parameters controlling hydrocarbon production from these shale reservoirs include: reservoir thickness, amount and type of organic matter, and thermal maturity (Milici, 1993; Curtis, 2002; Passey and others, 2010). The purpose of this report is to present maps and a cross section showing levels of thermal maturity, based on vitrinite reflectance $\left(\mathrm{R}_{\mathrm{o}}\right)$, for selected Upper Cretaceous marine shales in the Bighorn Basin.

\section{Stratigraphy}

Figure 3 is a correlation diagram showing the stratigraphic nomenclature for Upper Cretaceous marine shales and associated rocks in the Bighorn Basin, and the relationship to various localities in the Powder River Basin to the east. The Bighorn Basin nomenclature was compiled from Keefer (1972), Gill and Burkholder (1979), Merewether and Cobban (1986), Cobban and Kennedy (1989), Obradovich (1993), Merewether (1996), Obradovich and others (1996), Merewether and others (1997), Keefer and others (1998), and Kirschbaum and others (2009); the Powder River Basin nomenclature was modified from Merewether (1996). The stratigraphic relationships and nomenclature for the Bighorn Basin are also shown on the regional cross section in figure 4 .

\section{Mowry Shale}

The Mowry Shale was defined by Darton (1904) for exposures in the northwestern part of the Powder River Basin. The top of the Mowry was revised by Rubey (1931) to include the Clay Spur Bentonite Bed. In the Bighorn Basin no definitive correlation can be made to the Clay Spur, but based on comparisons with well logs in the northern Wind River Basin and the Casper arch area, the top of the Mowry is placed at a distinctive high-gamma geophysical log response (Finn, 2010b; Johnson, 2010). According to Keefer and others (1998), the Mowry Shale in the Bighorn Basin consists of two 


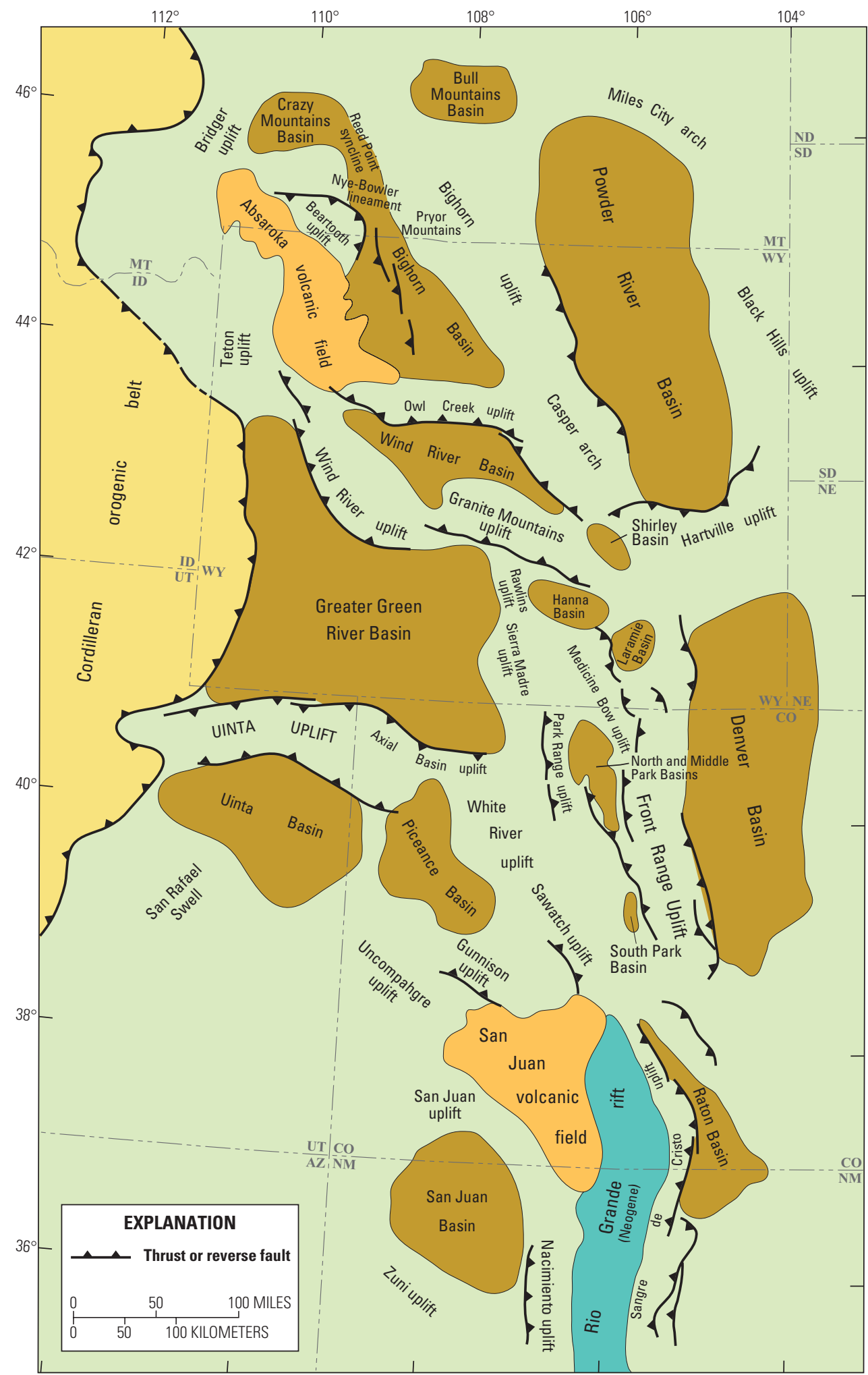

Figure 1. Map of Rocky Mountain region extending from southern Montana to northern New Mexico showing locations of Laramide sedimentary and structural basins (in brown) and intervening uplifts. Modified from Dickinson and others (1988). 


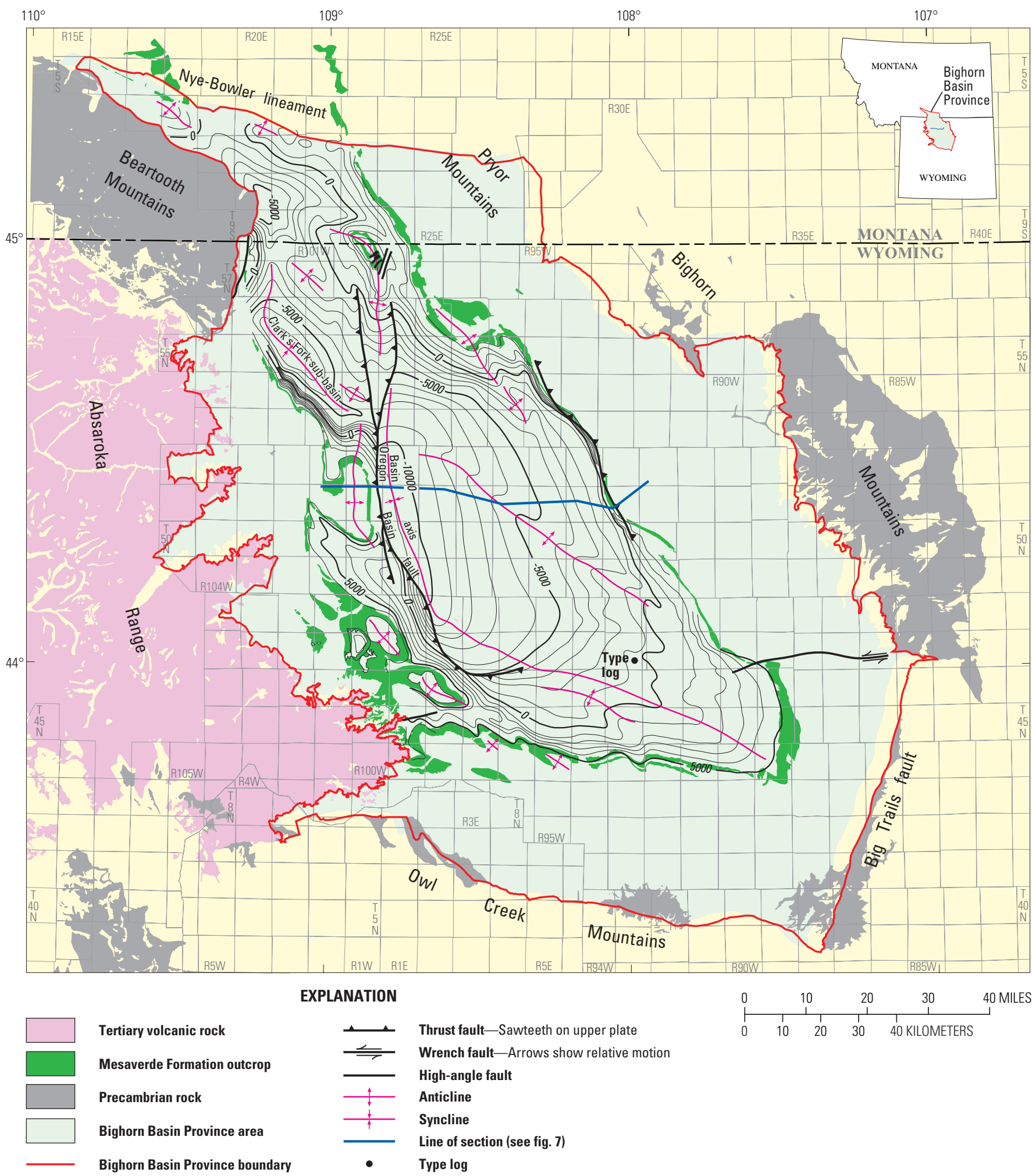

Figure 2. Index map of the Bighorn Basin in Wyoming and Montana showing major structural and physiographic features. Structure contours are drawn on top of the Mesaverde Formation. Bighorn Basin Province boundary from Finn and others (2010). Outcrops from Green and Drouillard (1994), and Raines and Johnson (1995). Contour interval = 5,000 feet. 


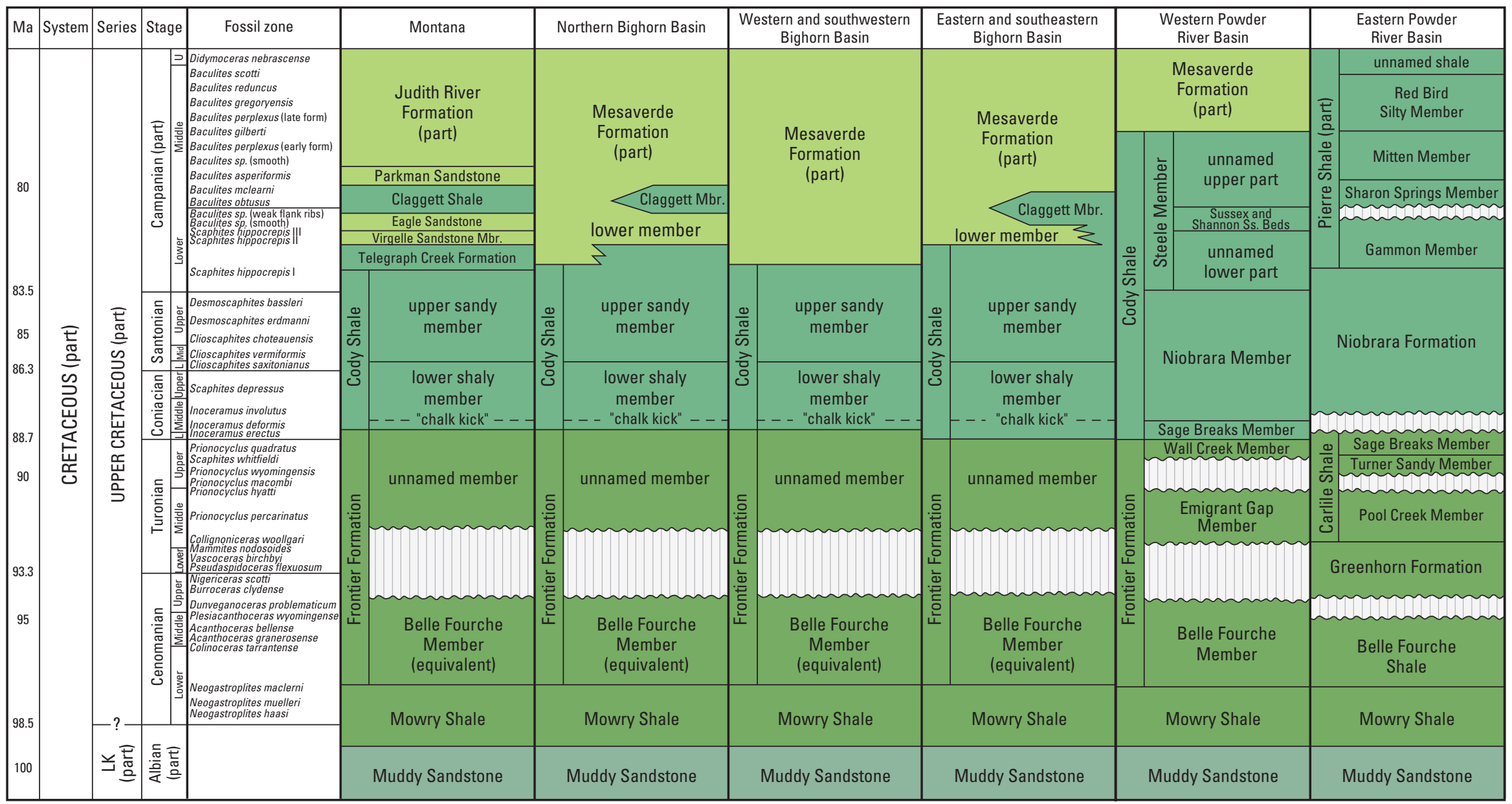

Figure 3. Correlation chart showing the stratigraphic relation of lowermost Upper Cretaceous rocks in the Bighorn Basin. Radiometric ages and fossil zones are from Obradovich (1993), and Merewether and others (1997). LK, Lower Cretaceous. 


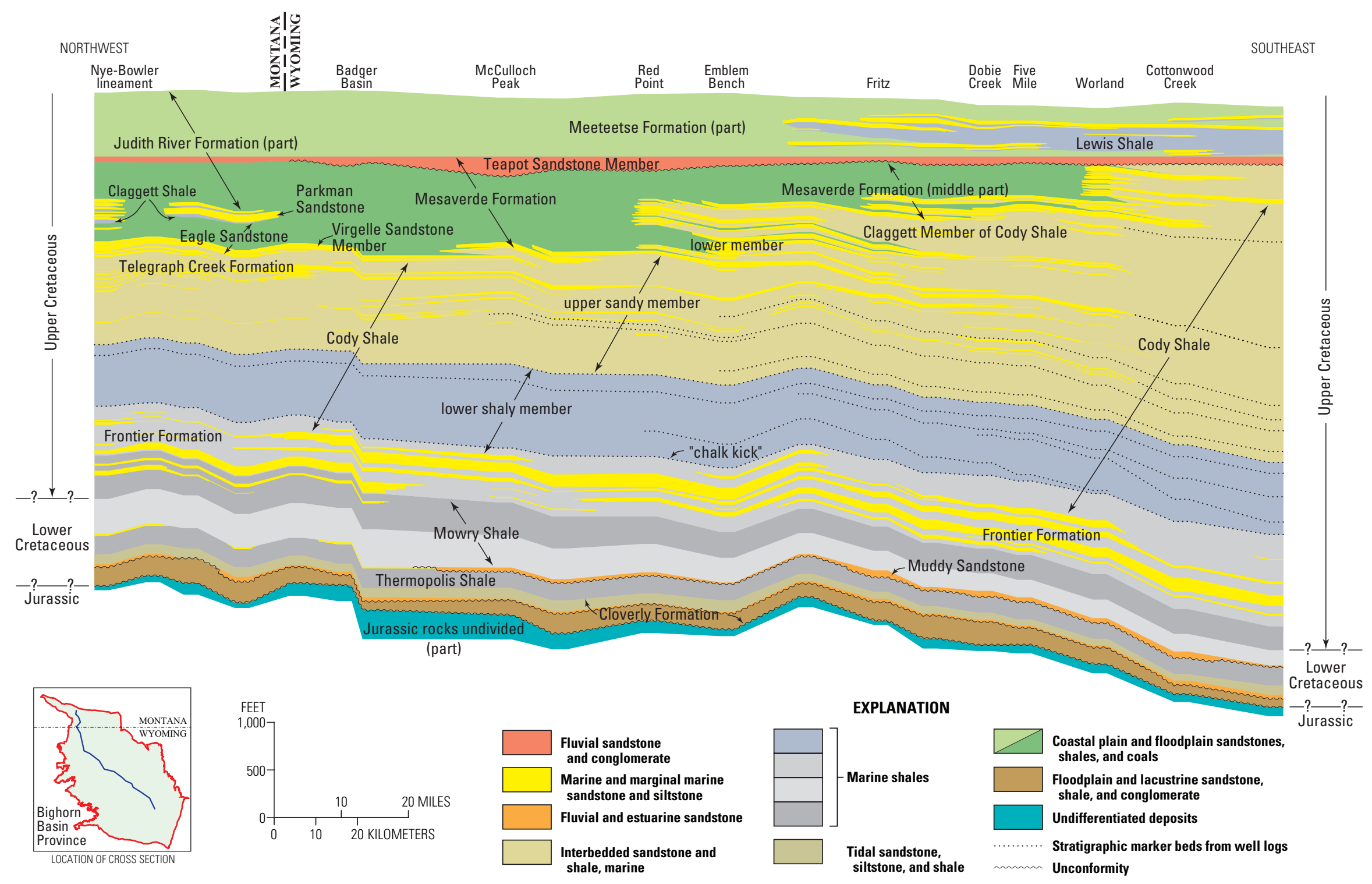

Figure 4. Regional northwest-southeast stratigraphic cross section of Cretaceous rocks in the Bighorn Basin. Modified from Finn (2010b). 
distinct units. The lower unit consists of about 150 to $400 \mathrm{ft}$ of soft fissile clay-rich shale similar to the older Thermopolis Shale and is referred to as the upper Thermopolis Shale by several authors including Mills (1956) and Haun and Barlow (1962), and as the Shell Creek Shale by Eicher (1962). The upper unit consists of about 240 to $400 \mathrm{ft}$ of hard brittle siliceous shale. Numerous gray to tan bentonite beds are common throughout the Mowry, ranging in thickness from less than one inch to about $7 \mathrm{ft}$ (Byers and Larson, 1979). The siliceous shales are dark brown to black, organic-rich, and contain an abundance of fish scales (Burtner and Warner, 1984). Locally, there are thin fine-grained sandstones in the middle to upper siliceous part of the Mowry. These units, referred to informally as the "Kimball" and "Octh Louie" sands, have produced oil from fields on the east side of the Bighorn Basin (Pierce, 1948; Mills, 1956; Cardinal and others, 1989). Davis (1987) also described two sandstone bodies in the Mowry Shale along the east and northeast sides of the basin. These sandstones are fine- to medium-grained, as much as $15 \mathrm{ft}$ thick, and form elongate bodies that he believed (Davis, 1987) were deposited during a fall in sea level. The Mowry Shale is marine in origin with a combined thickness for the lower and upper parts ranging from about $400 \mathrm{ft}$ in the southeastern part of the basin to more than $800 \mathrm{ft}$ near the Beartooth Mountains (Finn and others, 2010). Paleontologic evidence and radiometric dating indicate the upper siliceous part of the Mowry is largely early Cenomanian in age (Cobban and Kennedy, 1989; Obradovich and others, 1996); however, radiometric dates for bentonite beds in the basal Mowry (Shell Creek Shale of Eicher, 1962) indicate an Albian (Early Cretaceous) age (Obradovich and others, 1996).

\section{Frontier Formation}

The Frontier Formation is early Cenomanian to early Coniacian in age and contains at least one major unconformity in the upper part (Merewether and others, 1975; Kirschbaum and others, 2009). The contact with the underlying Mowry Shale is placed at a distinctive gamma response on geophysical logs that is believed to correspond to the Clay Spur Bentonite Bed that is considered the top of the Mowry Shale in the Powder River Basin. The upper contact is typically placed at the top of the uppermost sandstone below the Cody Shale. The Frontier interval, as defined between the top of the Mowry and uppermost sandstone bed, ranges in thickness from less than $200 \mathrm{ft}$ in the northern part of the basin to nearly $700 \mathrm{ft}$ in the southeastern part of the basin. The Frontier Formation consists of marine and minor marginal-marine shale, siltstone, and sandstone that are generally interpreted to be deltaic or shoreface in origin (Hunter, 1952; Goodell, 1962; Van Houten, 1962; Merewether and others, 1975; Siemers, 1975; Merewether and others, 1998; Kirschbaum and others, 2009). The sandstones are continuous for tens of miles, but pinch out into marine shale or are truncated along their upper surfaces by marine-flooding surfaces (Kirschbaum and others, 2009). Minor amounts of carbonaceous shale and coal are present in the northwestern part of the basin (Merewether and others, 1975; Siemers, 1975).

\section{Cody Shale}

The Cody Shale in the Bighorn Basin consists of marine shale, sandstone, and siltstone deposited during a major marine transgressive-regressive cycle that extended from Coniacian to Campanian time (Kauffman, 1977). The lower and upper parts of the Cody Shale interfinger extensively with the underlying Frontier and overlying Mesaverde Formations (fig. 4). The Cody ranges in thickness from about 1,700 $\mathrm{ft}$ in the northern part of the basin to nearly $3,800 \mathrm{ft}$ in the southeastern part (Finn and others, 2010). This southeastward thickening is due to the eastward stratigraphic rise and intertonguing of the contact between the Cody and the overlying Mesaverde Formation (fig. 4). In the Bighorn Basin, three members are recognized: (1) the informally named lower shaly member, (2) the informally named upper sandy member, and (3) the Claggett Member (Keefer, 1972; Keefer and others, 1998).

The lower shaly member is about 700 -ft thick in the northern part of the basin and reaches a maximum thickness of about 1,200 ft in the southern part (Finn, in press). It is composed of gray to black shale, calcareous shale, bentonite, and minor amounts of sandstone and siltstone. The contact between the lower and upper members is poorly defined and indistinct, and in this report is drawn at a distinctive well log marker that can be traced in the subsurface throughout the basin (fig. 5). A persistent zone referred to as the "chalk kick" marker by Keefer (1972) is recognized in geophysical logs in the lower part of the lower shaly member (fig. 5). This zone can be traced throughout the basin and separates calcareous shales above, from noncalcareous shales below. Based on regional correlations across the Casper arch and Wind River Basin, the calcareous interval extending from the "chalk kick" marker to the base of the overlying sandy member is equivalent to the lower shaly member of the Cody Shale in the western part of the Wind River Basin, and the basal part of the Niobrara Formation in the Powder River Basin to the east. This interval reaches a maximum thickness of about $1,000 \mathrm{ft}$ in the southwestern part of the basin and thins to about $500 \mathrm{ft}$ in the northeastern part of the basin (Finn, in press). The interval extending downward from the "chalk kick" marker to the top of the uppermost sandstone bed of the Frontier Formation ranges in thickness from about 100 to $400 \mathrm{ft}$, and is equivalent to the uppermost part of the Carlile Shale of the Powder River Basin (Finn, in press).

The upper sandy member of the Cody Shale is about 2,700 $\mathrm{ft}$ thick in the southern part of the Bighorn Basin and thins to around $1,000 \mathrm{ft}$ in the northern part. It consists of interbedded light to medium gray, or buff sandstones, and gray shales with the amount of sandstone increasing in the upper 500-1,200 ft (Johnson and others, 1998). In the subsurface, the sandstones in the upper part of the Cody can be traced over many miles and appear to pinch out into marine shale 
<smiles>COC(C)C</smiles>

Snyder Oil 1-26 Worland-Fee

sec. 26, T. 47 N., R. 93 W.

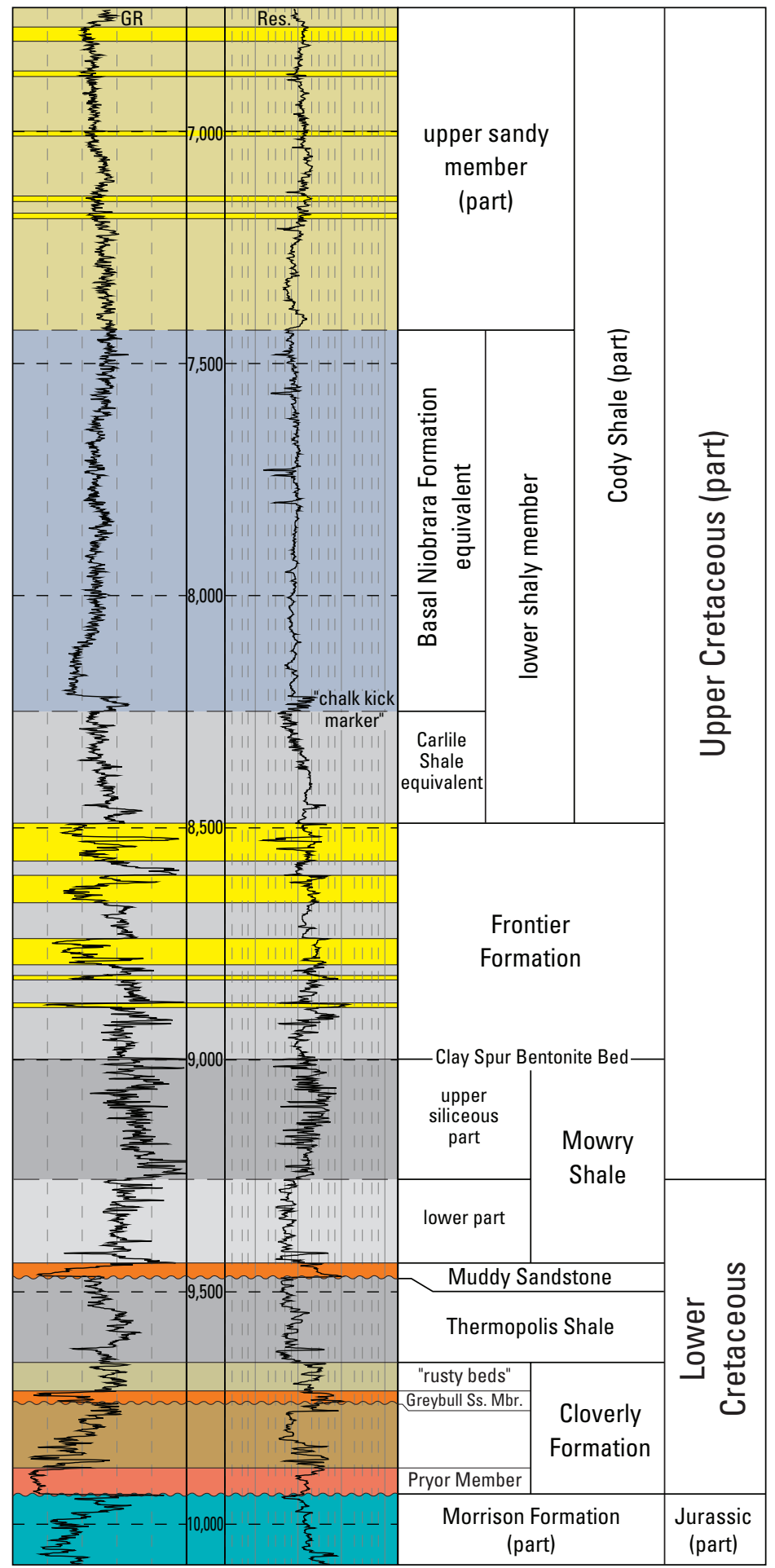

Figure 5. Type log of Lower Cretaceous and lowermost Upper Cretaceous rocks in the southeastern part of the Bighorn Basin. Sandstones and conglomerates of predominantly fluvial origin are shown in red; marine and marginal marine sandstones and siltstones, yellow; marine shales, various shades of gray; estuarine and fluvial sandstones shown in orange; floodplain and lacustrine sandstone and shale, brown; tidal sandstone, siltstone, and shale, light brown; interbedded marine sandstone and shale, tan; undifferentiated rocks, blue. GR, gamma ray; Res, resistivity. Location shown in figure 2. 
in all directions (Finn, 2010b; Johnson, 2010). The uppermost several hundred feet of the sandy member of the Cody is commonly referred to as the Telegraph Creek Formation in the Montana part of the basin (figs. 3 and 4). The Cody is poorly exposed; however, limited outcrop studies by Johnson and others (1998) of the uppermost Cody Shale indicate that the sandstones are very fine- to medium-grained, generally laterally persistent, and exhibit a variety of bedding features including hummocky cross-bedding, indicative of a nearshore marine origin.

According to Keefer and others (1998), the Claggett Member (known as the Claggett Shale in Montana) is a westward-thinning tongue of marine shale and fine-grained sandstone that is separated from the main part of the Cody Shale by the lower member of the Mesaverde Formation or its equivalent in Montana, the Eagle Sandstone (fig. 4). The Claggett Member extends across the eastern and central parts of the Bighorn Basin, and thickens eastward from zero to nearly $500 \mathrm{ft}$ thick at its eastern limit, where it merges with the main part of the Cody Shale (fig. 4) (Finn and others, 2010).

\section{Thermal Maturity Maps}

Maps showing thermal maturity levels based on vitrinite reflectance $\left(R_{0}\right)$ for Upper Cretaceous marine shales are shown on sheets 1-3. The maps were constructed using $R_{0}$ data published by Hagen and Surdam (1984), Hagen (1986), Yin (1997), Nuccio and Finn (1998), Finn and Pawlewicz (2007), Roberts and others (2008), and Pawlewicz and Finn (2012) from samples collected from oil and gas well cuttings, and outcrops. For wells reporting $\mathrm{R}_{\mathrm{o}}$ measurements over a range of depths, these data were plotted on a $\log \left(R_{o}\right)$ versus depth graph for each well and a visual best-fit line was drawn through the data, for example see figure 6. Data points appearing to be anomalously high or low with respect to the main trend were disregarded. In some cases, data from closely associated wells were combined into a composite $\log \left(\mathrm{R}_{\mathrm{o}}\right)$ versus depth plot. For a single well or outcrop location where few $R_{0}$ measurements were available over a short depth range or stratigraphic interval, the available data were averaged and the calculated $\mathrm{R}_{\mathrm{o}}$ were plotted for that location.

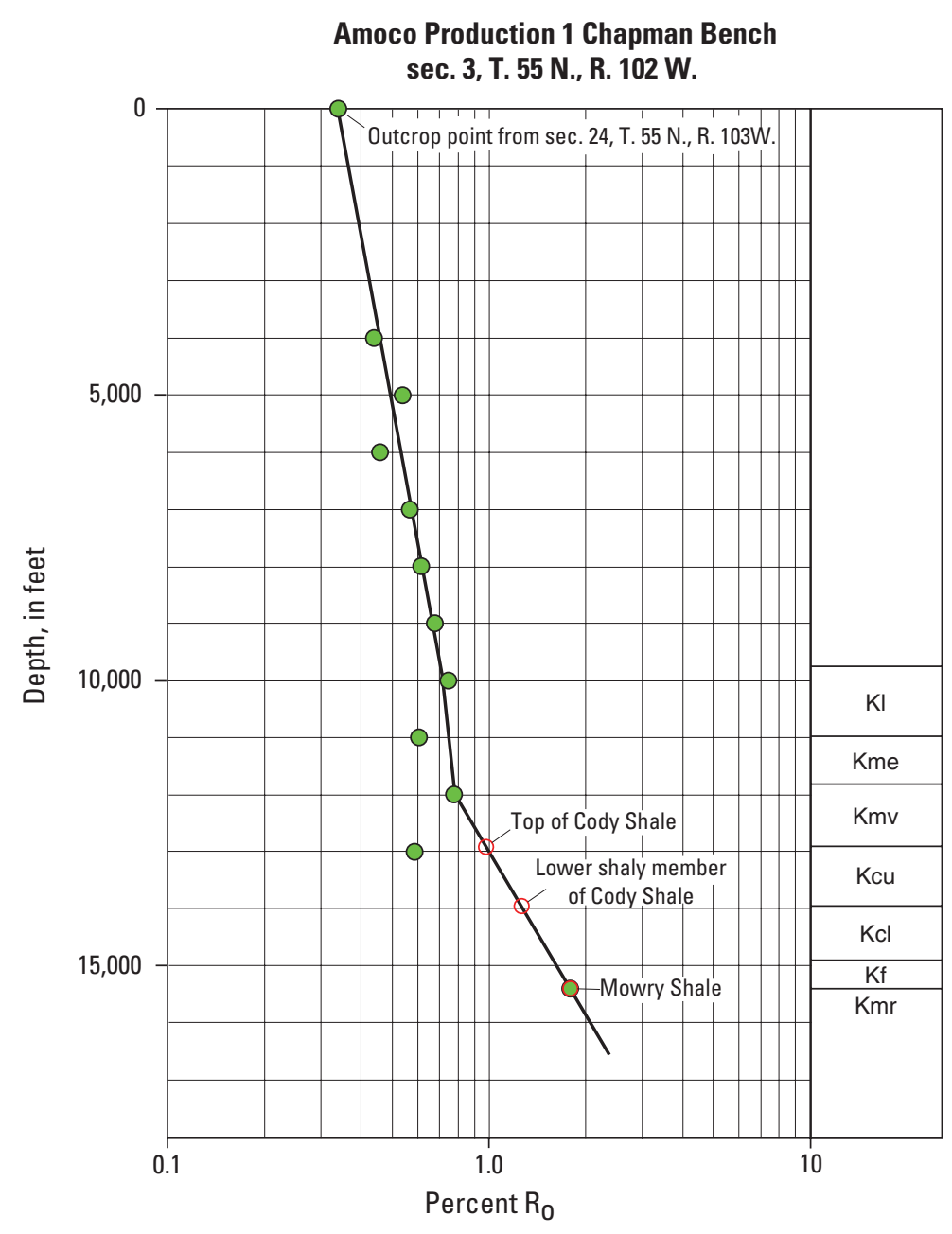

Figure 6. $\log \left(R_{0}\right)$ versus depth plot for the Amoco Production 1 Chapman Bench well. Kl, Lance Formation; Kme, Meeteetse Formation; Kmv, Mesaverde Formation; Kcu, upper sandy member of Cody Shale; Kcl, lower shaly member of Cody Shale; Kf, Frontier Formation; Kmr, Mowry Shale. 


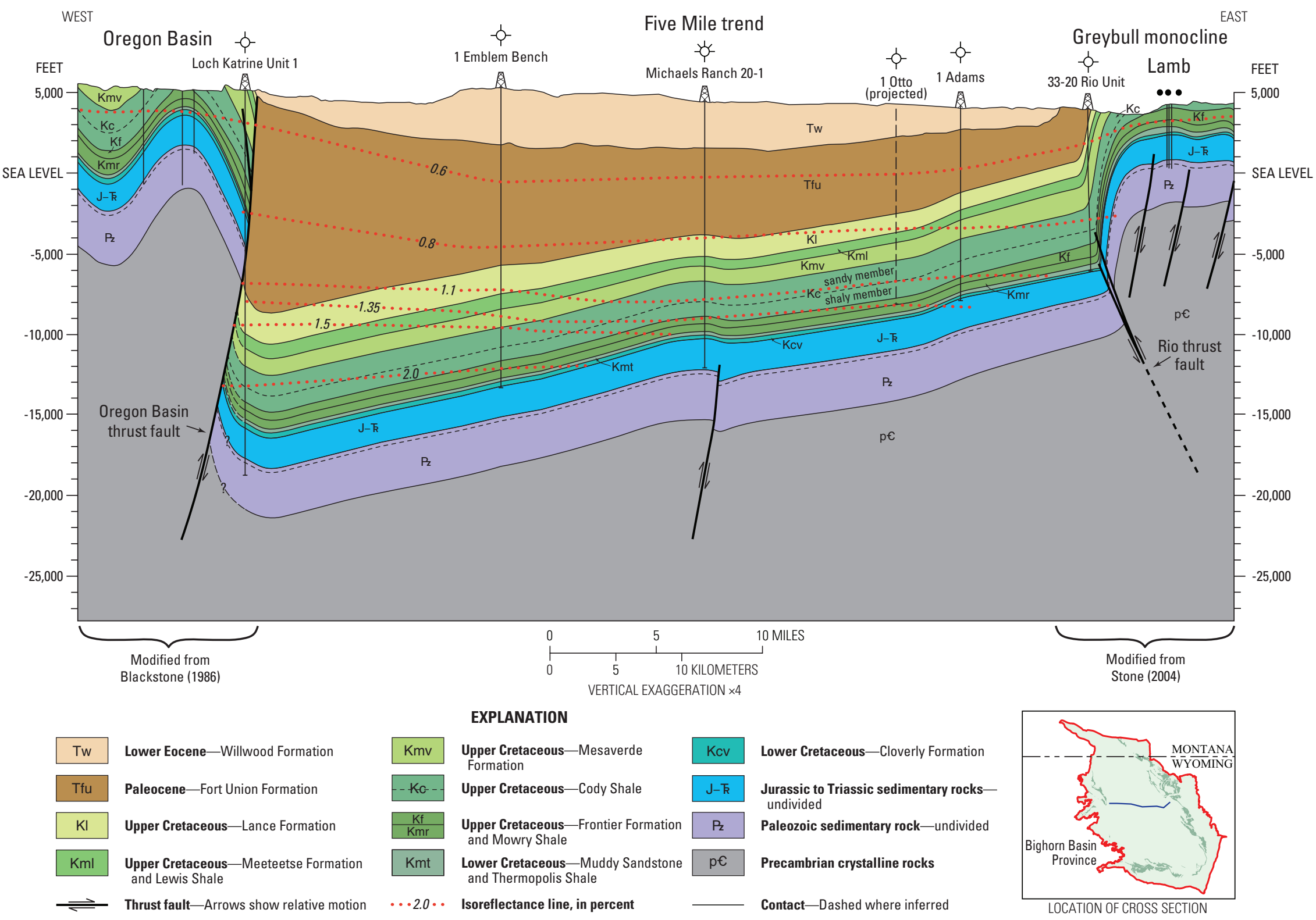

Figure 7. West-east structural cross section of the central part of the Bighorn Basin, Wyoming and Montana, showing relation between present-day structure and levels of thermal maturity based on vitrinite reflectance. Line of section shown in figure 2, and sheets 1-3. The Oregon Basin part of the section is modified from Blackstone (1986), the Greybull monocline part of the section is modified from Stone (2004). 
Three maps were constructed to show the thermal maturity of Upper Cretaceous marine shales in the Bighorn Basin: (1) top of the Cody Shale, (2) top of the lower shaly member of the Cody Shale (basal Niobrara Formation equivalent), and (3) the top of the Mowry Shale (sheets 1-3).

- Due to the intertonguing nature of the upper contact of the Cody Shale and the overlying Mesaverde Formation it was necessary to change the contoured horizon across the map from west to east (figs. 3, 4, and sheet 1). In the western and southwestern part of the basin the contours are drawn at the base of the main part of the Mesaverde Formation. In the central and northern part of the basin the contours are drawn at the base of the lower member of the Mesaverde Formation or its equivalent, the Eagle Sandstone in Montana. In the eastern and southeastern parts of the basin, where the lower member is absent, the contours are drawn at the base of the Mesaverde Formation (figs. 3 and 4, and sheet 1).

- The $\mathrm{R}_{\mathrm{o}}$ map for the top of the lower shaly member of the Cody Shale is contoured at the contact between the shaly member and the overlying sandy member (fig. 5, and sheet 2).

- The $\mathrm{R}_{\mathrm{o}}$ map for the Mowry Shale is drawn on a distinctive high gamma marker on geophysical logs that corresponds to the Clay Spur Bentonite Bed (fig. 5, and sheet 3).

All three mapped horizons show a general increase in thermal maturity from the margins of the basin into the deeper parts (sheets 1-3). In each case, the $\mathrm{R}_{\mathrm{o}}$ ranges from less than 0.6 to around 0.8 percent along the shallow margins of the basin, increasing to greater than 1.1 percent in the deeper parts along the main basin trough east of the Oregon Basin fault, in the Clark's Fork sub-basin, and a small area near the eastern end of the Beartooth Mountains uplift (sheets 1-3). In these structurally deeper parts of the basin, both the lower Cody Shale and Mowry Shale $\mathrm{R}_{\mathrm{o}}$ values exceed 1.35 percent. In the deepest part of the basin along the main synclinal trough, adjacent to and east of the Oregon Basin fault they both exceed 2.0 percent $R_{0}$ (sheets $2-3$ ). These thermal maturity trends generally reflect the structural configuration of the basin and indicate that large areas of the basin are thermally mature $\left(\mathrm{R}_{\mathrm{o}}>\sim 0.6\right.$ percent) to overmature $\left(\mathrm{R}_{\mathrm{o}}>\sim 1.35\right.$ percent) with respect to oil generation based on parameters defined by Peters and Cassa (1994). A structural cross section extending west-east across the central part of the basin illustrates the relation between the present-day structural configuration of the basin and thermal maturity (fig. 7). The isoreflectance lines are sub-parallel, nearly horizontal and cut across present-day structures indicating that maturation developed mainly after basin formation and deformation during the Laramide orogeny and subsequent accumulation of basin fill (Bustin and others, 1983).

\section{Acknowledgments}

The manuscript and sheets benefited from reviews by Ron Johnson, Laura Biewick, Dave Ferderer, and Tom Judkins, and their suggestions and comments are greatly appreciated.

\section{References}

Blackstone, D.L., Jr., 1986, Structural geology-Northwest margin, Bighorn basin-Park County, Wyoming and Carbon County, Montana, in Garrison, P.B., ed., Geology of the Beartooth uplift and adjacent basins: Yellowstone Bighorn Research Association-Montana Geological Society 50th Anniversary Guidebook, p. 125-135.

Burtner, R.L., and Warner, M.A., 1984, Hydrocarbon generation in Lower Cretaceous Mowry and Skull Creek Shales of the northern Rocky Mountain area, in Woodward, Jane, Meissner, F.F., and Clayton, J.L., eds., Hydrocarbon source rocks of the greater Rocky Mountain Region: Rocky Mountain Association of Geologists Guidebook, p. 449-467.

Bustin, R.M., Cameron, A.R., Grieve, D.A., and Kalkreuth, W.D., 1983, Coal petrology, its principles, methods, and applications: Geological Association of Canada, Short Course Notes, v. 3, 230 p.

Byers, C.W., and Larson, D.W., 1979, Paleoenvironments of Mowry Shale (Lower Cretaceous), western and central Wyoming: American Association of Petroleum Geologists Bulletin, v. 63, no. 3, p. 354-361.

Cardinal, D.F., Miller, Terry, Stewart, W.W., and Trotter, J.F., eds., 1989, Wyoming oil and gas fields symposium; Bighorn and Wind River Basins: Wyoming Geological Association, $560 \mathrm{p}$.

Clayton, J.L., and Swetland, P.J., 1977, Preliminary reportPetroleum geochemistry of the Denver Basin, in Veal, H.K., ed., Exploration frontiers of the central and southern Rockies: Rocky Mountain Association of Geologists, p. 223-233.

Cobban, W.A., and Kennedy, W.J., 1989, The ammonite Metengonoceras Hyatt, 1903, from the Mowry Shale (Cretaceous) of Montana and Wyoming: U.S. Geological Survey Bulletin 1787-L, $11 \mathrm{p}$.

Curtis, J.B., 2002, Fractured shale-gas systems: American Association of Petroleum Geologists Bulletin, v. 86, no. 11, p. 1921-1938.

Darton, N.H., 1904, Comparison of the stratigraphy of the Black Hills, Bighorn Mountains, and Rocky Mountain Front Range: Geological Society of America Bulletin, v. 15, p. 379-448. 
Davis, H.R., 1986, Amount and type of organic matter in the Cretaceous Mowry Shale of Wyoming: U.S. Geological Survey Open-File Report 86-412, 17 p.

Davis, H.R. 1987, Deposition of the Lower Cretaceous Mowry Shale: Madison, University of Wisconsin, Ph.D. dissertation, $217 \mathrm{p}$.

Davis, H.R., Byers, C.W., and Pratt, L.M., 1989, Depositional mechanisms and organic matter in Mowry Shale (Cretaceous), Wyoming: American Association of Petroleum Geologists Bulletin, v. 73, no. 9, p. 1103-1116.

De Bruin, R.H., 1993, Overview of oil and gas geology of Wyoming, in Snoke, A.W., Steidtmann, J.R., and Roberts, S.M., eds., Geology of Wyoming: Geological Survey of Wyoming Memoir No. 5, p. 836-873.

Dickinson, W.R., Klute, M.A., Hayes, M.J., Janecke, S.U., Lundin, E.R., McKittrick, M.A., and Olivares, M.D., 1988, Paleogeographic and paleotectonic setting of Laramide sedimentary basins in the central Rocky Mountain region: Geological Society of America Bulletin, v. 100, p. 1023-1039.

Eicher, D.L., 1962, Biostratigraphy of the Thermopolis, Muddy, and Shell Creek Formations, in Enyert, R.L., and Curry, W.H., III, eds., Symposium on Early Cretaceous rocks of Wyoming and adjacent areas: Wyoming Geological Association 17th Annual Field Conference, p. 72-93.

Finn, T.M., 2010a, New source rock data for the Thermopolis and Mowry Shales in the Wyoming part of the Bighorn Basin, in USGS Bighorn Basin Province Assessment Team, Petroleum Systems and Geologic Assessment of Oil and Gas in the Bighorn Basin Province, Wyoming and Montana: U.S. Geological Survey Digital Data Series DDS-69-V, Chapter 4, 15 p., CD-ROM.

Finn, T.M., 2010b, Subsurface stratigraphic cross sections showing correlation of Cretaceous and Lower Tertiary rocks in the Bighorn Basin, Wyoming and Montana, in USGS Bighorn Basin Province Assessment Team, Petroleum Systems and Geologic Assessment of Oil and Gas in the Bighorn Basin Province, Wyoming and Montana: U.S. Geological Survey Digital Data Series DDS-69-V, Chapter 6, 14 p., CD-ROM.

Finn, T.M., (in press), Lower Cody Shale (Niobrara equivalent) in the Bighorn Basin, Wyoming and Montana-Thickness, distribution, and source rock potential: U.S. Geological Survey Scientific Investigations Report 2013-5138.

Finn, T.M., Kirschbaum, M.A., Roberts, S.B., Condon, S.M., Roberts, L.N.R., and Johnson, R.C., 2010, Cretaceous-Tertiary composite total petroleum system (503402), Bighorn Basin, Wyoming and Montana, in USGS Bighorn Basin Province Assessment Team, Petroleum Systems and Geologic Assessment of Oil and Gas in the Bighorn Basin Province, Wyoming and Montana: U.S. Geological Survey Digital Data Series DDS-69-V, Chapter 3, 146 p., CD-ROM.
Finn, T.M., and Pawlewicz, M.J., 2007, New vitrinite reflectance data for the Bighorn Basin, north-central Wyoming and south-central Montana: U.S. Geological Survey OpenFile Report 2007-1246, 9 p.

Fox, J.E., and Dolton, G.L., 1989, Petroleum geology of the Wind River and Bighorn Basins, Wyoming and Montana: U.S. Geological Survey Open-File Report 87-450P, 41 p.

Fox, J.E., and Dolton, G.L., 1996a, Bighorn Basin Province; in Gautier, D.L., Dolton, G.L., Takahashi, K.I., and Varnes, K.L., eds., 1995 National assessment of United States oil and gas resources-Results, methodology, and supporting data: U.S. Geological Survey Digital Data Series DDS-30, Release 2, CD-ROM.

Fox, J.E., and Dolton, G.L., 1996b, Petroleum geology of the Bighorn Basin, north-central Wyoming and south-central Montana; in Bowen, C.E., Kirkwood, S.C., and Miller, T.S., eds., Resources of the Bighorn Basin: Wyoming Geological Association Guidebook, p. 19-39.

Gill, J.R., and Burkholder, R.E., 1979, Measured sections of the Montana Group and equivalent rocks from Montana and Wyoming: U.S. Geological Survey Open-File Report 79-1143, $202 \mathrm{p}$.

Goodell, H.G., 1962, The stratigraphy and petrology of the Frontier Formation of Wyoming, in Enyert, R.L., and Curry, W.H., eds., Symposium on Early Cretaceous rocks of Wyoming and adjacent areas: Wyoming Geological Association 17th Annual Field Conference Guidebook, p. 175-210.

Green, G.N., and Drouillard, P.H., 1994, The digital geologic map of Wyoming in ARC/INFO format: U.S. Geological Survey Open-File Report 94-0425, scale 1:500,000.

Hagen, E.S., 1986, Hydrocarbon maturation in Laramide-style basins - Constraints from the northern Bighorn Basin, Wyoming and Montana: Laramie, University of Wyoming, Ph.D. dissertation, $215 \mathrm{p}$.

Hagen, E.S., and Surdam, R.C., 1984, Maturation history and thermal evolution of Cretaceous source rocks of the Bighorn Basin, Wyoming and Montana, in Woodward, Jane, Meissner, F.F., and Clayton, J.L., eds., Hydrocarbon source rocks of the greater Rocky Mountain region: Rocky Mountain Association of Geologists Guidebook, p. 321-338.

Haun, J.D., and Barlow, J.A., Jr., 1962, Lower Cretaceous stratigraphy of Wyoming, in Enyert, R.L., and Curry, W.H., eds., Symposium on Early Cretaceous rocks of Wyoming and adjacent areas: Wyoming Geological Association 17th Annual Field Conference Guidebook, p. 15-22.

Hunter, L.D., 1952, Frontier Formation along the eastern margin of the Big Horn Basin, Wyoming, in Spalding, R.W., and Wold, J.S., eds., Southern Big Horn Basin: Wyoming Geological Association 7th Annual Field Conference Guidebook, p. 63-66. 
Johnson, R.C., 2010, Detailed west to east cross section of Cretaceous and Lower Tertiary rocks across the south part of the Bighorn Basin, Wyoming, in USGS Bighorn Basin Assessment Team, Petroleum Systems and Geologic Assessment of Oil and Gas Resources in the Bighorn Basin Province, Wyoming and Montana: U.S. Geological Survey Digital Data Series DDS-69-V, Chapter 7, 3 p., CD-ROM.

Johnson, R.C., Crovelli, R.A., Lowell, B.G., and Finn, T.M., 1999, An assessment of in-place gas resources in the low-permeability basin-centered gas accumulation of the Bighorn Basin, Wyoming and Montana: U.S. Geological Survey Open-File Report 99-315-A, 123 p.

Johnson, R.C., and Finn, T.M., 1998, Is there a basin-centered gas accumulation in Upper Cretaceous rocks in the Bighorn Basin?, in Keefer, W.R., and Goolsby, J.E., eds., Cretaceous and Lower Tertiary rocks of the Bighorn Basin, Wyoming and Montana: Wyoming Geological Association 49th Annual Field Conference Guidebook, p. 257-273.

Johnson, R.C., Keefer, W.R., Keighin, C.W., and Finn, T.M., 1998, Detailed outcrop studies of the upper part of the Upper Cretaceous Cody Shale and The Upper Cretaceous Mesaverde, Meeteetse, and Lance Formations, Bighorn Basin, Wyoming, in Keefer, W.R., and Goolsby, J.E., eds., Cretaceous and Lower Tertiary rocks of the Bighorn Basin, Wyoming and Montana: Wyoming Geological Association 49th Annual Field Conference Guidebook, p. 59-78.

Kauffman, E.G., 1977, Geological and biological overviewWestern Interior Cretaceous Basin, in Kauffman, E.G., ed., Cretaceous facies, faunas, and paleoenvironments across the Western Interior Basin: The Mountain Geologist, v. 14, nos. 3 and 4, p. 75-99.

Keefer, W.R., 1972, Frontier, Cody, and Mesaverde Formations in the Wind River and southern Bighorn Basins, Wyoming: U.S. Geological Survey Professional Paper 495-E, 23 p.

Keefer, W.R., Finn, T.M., Johnson, R.C., and Keighin, C.W., 1998, Regional stratigraphy and correlation of Cretaceous and Paleocene rocks, Bighorn Basin, Wyoming and Montana, in Keefer, W.R., and Goolsby, J.E., eds., Cretaceous and Lower Tertiary rocks of the Bighorn Basin, Wyoming and Montana: Wyoming Geological Association 49th Annual Field Conference Guidebook, p. 1-30.

Kirschbaum, M.A., Merewether, E.A., and Condon, S.M., 2009, Stratigraphy and age of the Frontier Formation and associated rocks, central and southern Bighorn Basin, Wyoming-Surface to subsurface correlation: The Mountain Geologist, v. 46, no. 4, p. 125-147.

Landon, S.M., Longman, M.W., and Luneau, B.A., 2001, Hydrocarbon source rock potential of the Upper Cretaceous Niobrara Formation, Western Interior Seaway of the Rocky Mountain region: The Mountain Geologist, v. 38, no. 1, p. $1-18$.
Longman, M.W., Luneau, B.A., and Landon, S.M., 1998, Nature and distribution of Niobrara lithologies in the Cretaceous Western Interior Seaway of the Rocky Mountain region: The Mountain Geologist, v. 35, no. 4, p. 137-170.

Meissner, F.F., Woodward, Jane, and Clayton, J.L., 1984, Stratigraphic relationships and distribution of source rocks in the greater Rocky Mountain region, in Woodward, Jane, Meissner, F.F., and Clayton, J.L., eds., Hydrocarbon source rocks of the greater Rocky Mountain region: Rocky Mountain Association of Geologists Guidebook, p. 1-34.

Merewether, E.A., 1996, Stratigraphy and tectonic implications of Upper Cretaceous rocks in the Powder River Basin, northeastern Wyoming and southeastern Montana: U.S. Geological Survey Bulletin 1917-T, 92 p.

Merewether, E.A., and Claypool, G.E., 1980, Organic composition of some Upper Cretaceous shale, Powder River Basin, Wyoming: American Association of Petroleum Geologists Bulletin, v. 64, no. 4, p. 488-500.

Merewether, E.A., and, Cobban, W.A., 1986, Biostratigraphic units and tectonism in the mid-Cretaceous foreland of Wyoming, Colorado, and adjoining areas-Part III. Middle Rocky Mountains, in Peterson, J.A., ed., Paleotectonics and sedimentation in the Rocky Mountain Region, United States: American Association of Petroleum Geologists Memoir 41, p. 443-468.

Merewether, E.A., Cobban, W.A., and Ryder, R.T., 1975, Lower Upper Cretaceous strata, Bighorn Basin, Wyoming and Montana, in Exum, F.A., and George, G.R., eds., Geology and mineral resources of the Bighorn Basin: Wyoming Geological Association 27th Annual Field Conference Guidebook, p. 73-84.

Merewether, E.A., Dolson, J.C., Hanson, W.B., Keefer, W.R., Law, B.E., Mueller, R.E., Ryer, T.A., Smith, A.C., Stilwell, D.P., and Wheeler, D.M., 1997, Cretaceous stratigraphy in a northeast-trending transect, northern Utah to south-central South Dakota: U.S. Geological Survey Map I-2609.

Merewether, E.A., Tillman, R.W., Cobban, W.A., and Obradovich, J.D., 1998, Outcrop-sections of the Upper Cretaceous Frontier Formation, southeastern Bighorn Basin, Wyoming, in Keefer, W.R., and Goolsby, J.E., eds., Cretaceous and lower Tertiary rocks of the Bighorn Basin, Wyoming and Montana: Wyoming Geological Association 49th Annual Field Conference Guidebook p. 31-42.

Milici, R.C., 1993, Autogenic gas (self sourced) from shalesAn example from the Appalachian Basin, in Howell, D.G., ed., The future of energy gases: U.S. Geological Survey Professional Paper 1570, p. 253-278.

Mills, N.K., 1956, Subsurface stratigraphy of the preNiobrara formations in the Big Horn Basin, Wyoming, in Burk, C.A., and others, Wyoming Stratigraphy, Part I, 
Subsurface stratigraphy of the pre-Niobrara formations in Wyoming: Wyoming Geological Association, Casper, Wyoming, p. 9-22.

Momper, J.A., and Williams, J.A., 1984, Geochemical exploration in the Powder River Basin, in Demaison, Gerard, and Murris, R.J., eds., Petroleum geochemistry and basin evaluation: American Association of Petroleum Geologists Memoir 35, p. 181-191.

Nixon, R.P., 1973, Oil source beds in Cretaceous Mowry Shale of northwestern interior United States: American Association of Petroleum Geologists Bulletin, v. 57, no. 1, p. $136-161$.

Nuccio, V.F., 1990a, Burial, thermal, and petroleum generation history of the Upper Cretaceous Steele Member of the Cody Shale (Shannon Sandstone Bed horizon), Powder River Basin, Wyoming: U.S. Geological Survey Bulletin 1917-A, $17 \mathrm{p}$.

Nuccio, V.F., 1990b, Determination of source-rock thermal maturity by direct measurements and predictive modelingapplication to Upper Cretaceous Cody Shale, Powder River Basin, Wyoming, in Nuccio, V.F., Barker, C.E., and Dyson, S.J., eds., Applications of thermal maturity studies to energy exploration: Rocky Mountain Section, Society of Economic Paleontologists and Mineralogists, p. 167-175.

Nuccio, V.F., and Finn, T.M., 1998, Thermal maturity and petroleum generation history of Cretaceous and Tertiary source rocks, Bighorn Basin, Wyoming and Montana, in Keefer, W.R., and Goolsby, J.E., eds., Cretaceous and Lower Tertiary rocks of the Bighorn Basin, Wyoming and Montana: Wyoming Geological Association 49th Annual Field Conference Guidebook, p. 211-231.

Obradovich, J.D., 1993, A Cretaceous time scale, in Caldwell, W.G.E., and Kauffman, E.G., eds., Evolution of the Western Interior Basin: Geological Association of Canada Special Paper 39, p. 379-96.

Obradovich, J.D., Cobban, W.A., Merewether, E.A., and Weimer, R.J., 1996, A time framework for the late Albian and early Cenomanian strata of northern Wyoming and Montana: Geological Society of America Abstracts with Programs, 1996 Annual Meeting, Denver, Colorado, v. 28, no. 7, p. A-66.

Passey, Q.R., Bohacs, K.M., Esch, W.L., Klimentidis, R., and Sinha, S., 2010, From oil-prone source rock to gas-producing shale reservoir-Geologic and petrophysical characterization of unconventional shale-gas reservoirs: Society of Petroleum Engineers Paper 131350, 29 p.

Pawlewicz, M.J., and Finn, T.M., 2012, Vitrinite reflectance data for Cretaceous marine shales and coals in the Bighorn Basin, north-central Wyoming and south-central Montana: U.S. Geological Survey Open-File Report 2012-1254, 11 p.
Peters, K.E., and Cassa, M.R., 1994, Applied source rock geochemistry, in Magoon, L.B., and Dow, W.G., eds., The petroleum system-from source to trap: American Association of Petroleum Geologists Memoir 60, p. 93-120.

Pierce, W.G., 1948, Geologic and structure contour map of the Basin-Greybull area, Bighorn County, Wyoming: U.S. Geological Survey Oil and Gas Investigations Preliminary Map 77, scale 1:48,000.

Raines, G.L., and Johnson, B.R., 1995, Digital representation of the Montana state geologic map; a contribution to the Interior Columbia River basin ecosystem management project: U.S. Geological Survey Open-File Report 95-691, 20 p.

Roberts, L.N.R., Finn, T.M., Lewan, M.D., and Kirschbaum, M.A., 2007, Burial history, thermal maturity, and oil and gas generation history of petroleum systems in the Wind River Basin province, central Wyoming, in USGS Wind River Basin Province Assessment Team, eds., Petroleum Systems and Geologic Assessment of Oil and Gas in the Wind River Basin Province, Wyoming: U.S. Geological Survey Digital Data Series DDS-69-J, Chapter 6, 26 p., CD-ROM.

Roberts, L.N.R., Finn, T.M., Lewan, M.D., and Kirschbaum, M.A., 2008, Burial history, thermal history, and oil and gas generation history of source rocks in the Bighorn Basin, Wyoming and Montana: U.S. Geological Survey Scientific Investigations Report 2008-5037, 28 p.

Roberts, L.N.R., Lewan, M.D., and Finn, T.M., 2004, Timing of oil and gas generation of petroleum systems in the southwestern Wyoming Province: The Mountain Geologist, v. 41 , no. 3 , p. $87-118$.

Rubey, W.W., 1931, Lithologic studies of fine-grained Upper Cretaceous sedimentary rocks of the Black Hills region, in Shorter contributions to general geology, 1930: U.S. Geological Survey Professional Paper, 165-A, p. A1-A54.

Ryder, R.T., 1987, Oil, gas, and coal resources of the McCullough Peaks Wilderness study area, Bighorn Basin, Wyoming: U.S. Geological Survey Open-File Report 87-646, 59 p.

Schrayer, G.J., and Zarrella, W.M., 1963, Organic geochemistry of shale-I. Distribution of organic matter in the siliceous Mowry Shale of Wyoming: Geochimica et Cosmochimica Acta, v. 27, no. 10, p. 1033-1046.

Schrayer, G.J., and Zarrella, W.M., 1966, Organic geochemistry of shale-II, Distribution of extractable organic matter in the siliceous Mowry Shale of Wyoming: Geochimica et Cosmochimica Acta, v. 30, no. 4, p. 415-434.

Schrayer, G.J., and Zarrella, W.M., 1968, Organic carbon in Mowry Formation and its relation to the occurrence of petroleum in Lower Cretaceous reservoir rocks, in Wulf, G.R., ed., Black Hills area South Dakota, Montana, 
Wyoming: Wyoming Geological Association 20th Field Conference Guidebook, p. 35-39.

Siemers, C.T., 1975, Paleoenvironmental analysis of the Upper Cretaceous Frontier Formation, northwestern Bighorn Basin, in Exum, F.A., and George, G.R., eds., Geology and mineral resources of the Bighorn Basin: Wyoming Geological Association 27th Annual Field Conference Guidebook, p. $85-100$.

Stone, D.S., 2004, Rio thrusting, multi-stage migration, and formation of vertically segregated Paleozoic oil pools at Torchlight field on the Greybull platform (eastern Bighorn Basin)-Implications for exploration: The Mountain Geologist, v. 41, no. 3, p. 119-138.

Surdam, R.C., Jiao, Z.S., and Heasler, H.P., 1997, Anomalously pressured gas compartments in Cretaceous rocks of the Laramide basins of Wyoming-A new class of hydrocarbon accumulation, in Surdam, R.C., ed., Seals, traps, and the petroleum system: American Association of Petroleum Geologists Memoir 67, p. 199-222.

Van Houten, F.B., 1962, Frontier Formation, Bighorn Basin, Wyoming in, Enyert, R.L., and Curry, W.H., eds., Symposium on Early Cretaceous rocks of Wyoming and adjacent areas: Wyoming Geological Association 17th Annual Field Conference Guidebook, p. 221-231.

Wilson, C.W., Jr., 1936, Geology of the Nye-Bowler lineament, Stillwater and Carbon Counties, Montana: American Association of Petroleum Geologists Bulletin, v. 20, no. 9, p. 1161-1188.

Yin, Peigui, 1997, Source rock maturation and diagenetic modeling in Badger Basin, in Campen, E.B., ed., Bighorn Basin-50 Years on the Frontier, Part 2: Yellowstone-Bighorn Research Association-Wyoming Geological Association-Montana Geological Society, 1997 Field Trip and Symposium, p. 41-44.

Publishing support provided by:

Denver Publishing Service Center

For more information concerning this publication, contact:

Center Director, USGS Central Energy Resources Science Center

Box 25046, Mail Stop 939

Denver, CO 80225

(303) 236-1647

Or visit the Central Energy Resources Science Center Web site at: http://energy.usgs.gov/ 
